\title{
Irrelevance of Inflation: The Dow Stocks
}

\author{
Samih Antoine Azar ${ }^{1}$ \\ ${ }^{1}$ Full Professor, Faculty of Business Administration \& Economics, Haigazian University, Lebanon \\ Correspondence: Samih Antoine Azar, Full Professor, Faculty of Business Administration \& Economics, Haigazian \\ University, Mexique Street, Kantari, Beirut, Lebanon.
}

Received: December 12, 2019

Accepted: January 3, 2020

Online Published: January 6, 2020

doi:10.5430/afr.v9n1p45

URL: https://doi.org/10.5430/afr.v9n1p45

\begin{abstract}
The irrelevance of inflation is a proposition, inherited from corporate finance, which states that inflation is irrelevant for the valuation of nominal and real stock prices. In other terms, Net Present Values (NPVs) and stock returns are independent of the inflation rate. The issue at stake is both theoretical and empirical, although the first came much before the latter. In the empirical realm, stock returns are found to be statistically negatively related to inflation. However, and theoretically, the classical school predicted that they should be related positively one-to-one. Moreover long run analysis, that came later, found that stock prices are positively related to price indexes. This stems from the fact that stocks are claims upon real assets, and, therefore, should be a hedge against inflation with the same one-to-one relation. This paper differs by subjecting all these hypotheses to the individual stocks included in the Dow Jones Industrial Index, and not to returns calculated from stock indexes, which is the usage. The empirical results in this paper support strongly the irrelevance of inflation. This is true whatever the price index, whatever the econometric procedure, whatever the industry to which the stock belongs, and whatever the specification of the model. Hence inflation is neither negatively nor positively related to stock returns, whether nominal or real.
\end{abstract}

Keywords: CPI and core inflation, nominal stock returns, real stock returns, 30 Dow stocks, S\&P 500, system estimation, panel least squares

\section{Introduction}

The relation between stocks and inflation is crucial for its link with monetary policy. If the relation is significant it indicates that the financial markets respond significantly to inflation shocks, and hence the stock markets may indicate early on the optimal stance of whether to undertake expansionary or restrictive policy. Inflation is a delayed statistic whereas stock markets provide instantaneous though noisy information. Unfortunately the issue is not that simple and is rather controversial, both theoretically and empirically.

Theoretically the relation can be positive, negative, or spurious. The empirical evidence provides evidence for the three signs, including no determinate sign. Chronologically the theory and the evidence are intertwined, except for the third indeterminate sign which is relatively recent, especially on empirical grounds. The paradigms are also non-chronological, swerving between finding a positive and a negative sign relation. Moreover these paradigms differ between financial economists and professors of corporate finance. The former, or economists, favor either a negative or a positive sign, while the latter mostly teach independence.

Historically, the positive relation prevailed (Fisher, 1930). The initial theory of the interest rate stated that the nominal rate is a sum of a real rate with expected inflation added to it, describing what has been dubbed the Fisher hypothesis. The real rate was assumed to be constant. Therefore the nominal rate varies directly with the expected inflation rate. Expectations can be either rational or adaptive, static, extrapolative, regressive, or based on forecasts, or, even, determined by short term T-bills or long term T-bonds, or simply obtainable with perfect foresight (Pilbeam, 2013).

In 1976, Bodie (1976), Nelson (1976) and Jaffe and Mandelker (1976), followed closely by Fama and Schwert (1977), discovered empirically that nominal interest rates varied negatively with inflation. This spurred a plethora of empirical studies, and a massive attempt to explain this negative relation theoretically. Some of these early empirical studies are Gultekin (1983) and Solnik (1983). Theoretically some invoked taxes (Feldstein, 1980), some posited money or inflation illusion (Modigliani and Cohn, 1979; Campbell and Vuolteenaho, 2004), some reverted to money demand theory and its link to the stock market (Fama, 1981), and some reversed the direction of the relation and explained it by monetary/fiscal transmission channels (Geske, and Roll, 1983). 
The paper of Engle \& Granger (1987) on cointegration has served to rehabilitate the original Fisher hypothesis by looking at the long run cointegration relation between stock indexes and the price level. Early research using cointegration has been carried out by Ely and Robinson (1997), and Anari and Kolari (2001). The former find evidence in support of cointegration between equities, inflation, real output and money supply. The latter concur with the former and find a cointegration relation between stock prices and price levels, dropping real output and money supply from the analysis. However, they acknowledge that the speed of adjustment to the long run is relatively slow. Later research on cointegration is referenced in Boamah (2017) and especially in Al-Nassar and Bhatti (2019). In short, the evidence for a long run cointegration relation between a stock index and the price level is not robust, although the long run can be apprehended alternatively by extending the investment horizon (Boudoukh and Richardson, 1993). In such a case the evidence to the Fisher relation is more supportive but also less stable given the work of Austin and Dutt (2016), who follow a similar strategy as in Boudoukh and Richardson (1993), but find little or no evidence for this relation. As another example the results in Boamah (2017) find that the t-statistic on the coefficient for the US error-correction variable is -1.64 , and that the speed of adjustment to the long run of around 5 years, both features that downplay the economic significance of these results. But the literature was supplemented by an additional theoretical argument: common stocks being claims on real assets should be a hedge against inflation of prices of real assets. Hence, this resurrected hedge argument predicts that stock prices, and not stock returns, should be positively related to the price level, and not to inflation, and that any loss in purchasing power should be compensated by a reward that eliminates the fall in wealth. This argument implies a similar relation as the one put forward by the Fisher hypothesis, and is usually referred to as the 'Generalized Fisher Hypothesis.' However, the presence of cointegration directly specifies an Error-Correction Model that contradicts weak form market efficiency, because stock prices become predictable by the lagged error-correction variables. Therefore the lack of evidence on cointegration may simply be due to market efficiency, and should be expected to happen on average. Cointegration will not be attempted in this paper and the specification is with the first-difference of the log levels, i.e. stock returns and inflation rates, instead of stock indexes and price indexes. To please pundits this approach can be called a short run analysis although the monthly data spans almost five decades.

If one desires to draw a conclusion from the empirical literature, it is that firm stocks react differently to inflation shocks: negatively in the short run, and positively in the very long run, or negatively for temporal shocks and positively for permanent ones. This is mirrored in the error-correction models. The short run, or the temporary effect, is captured by the variables in rates, and the very long run, or the more permanent effect, is determined by the lagged level of index variables. In this paper it is decided to omit the error-correction variable from the analysis since it is economically very small.

The above justification is difficult to rationalize theoretically, although many economists would agree to it and espouse it. Why should the impact be different in sign? A third generation of empirical studies, and which is the most recent, starts from the precepts of corporate finance, or more exactly from the teaching of corporate finance (Brealey et al., 2017), in contrast to economists. The theory is simple and outdated: the Net Present Value (NPV) of any investment is the same in nominal and real (or inflation-adjusted) terms. Nominal cash flows are discounted by nominal rates, and real cash flows are discounted by real rates, both producing the same present value. Since stocks and stock indexes are NPV values, they should be resilient to inflation. In efficient markets, this should be true irrelevant of inflation illusion, tax considerations, monetary channels of transmission, or what-have-you. Rejecting this precept is tantamount to rejecting a basic tenet of corporate finance. How, then, can one explain the empirical findings, about the difference in signs between short run and long run? Azar (2010) has argued that the empirical evidence is flawed and biased, either because of omitted fundamental variables, or from the specification of the model. He finds that the bias applies to inflation, expected inflation, unexpected inflation, and even for inflation uncertainty (Azar, 2013). Azar (2014a) adds to the list the US dollar, the choice of the econometric procedure, and the S\&P 500 stock market index. Azar (2014b) adds further the time series properties of the variables. Azar (2014b) concludes that the evidence is still strong in support of the irrelevance proposition that inflation has no impact on stock returns.

Moreover, since this study is on stocks included in the Dow Jones Industrial Index (DJIA), or Dow stocks, and these are mostly large, it is crucial to find whether there is any selection bias. Unfortunately, the literature is not helpful. Ang et al. (2012) write that the best inflation hedgers are large companies because they have a strong pricing power to change prices when inflation occurs. These menu costs are presumably a fixed cost, which will reduce the average total fixed cost as sales rebound. However, quite surprisingly, Ciner (2015) takes an opposite stand and states that small companies tend to be more flexible to adjust their prices and that they are better hedgers against inflation. Moreover, the Dow stocks are the most profitable, and have the highest probability of survival. These features may 
elicit their reaction to inflation. Hence, the question is the following: is insensitivity to inflation a characteristic of successful firms? A related matter is the following. Most research was undertaken on stock indexes, or their returns. Therefore the use of an index may show inflation neutrality by simple averaging, while the constituent stocks can have dispersed sensitivities to inflation, around neutrality. This paper will dispel these concerns. Inflation has no individual impact upon nominal returns, and also upon real returns, and so whatever the econometric procedure adopted, whatever the price index, from which the inflation rate is measured, whatever the industry, and whatever the specification of the model. This applies foremost to Dow stocks, and not only to stock indexes. Auspiciously neither aggregation nor disaggregation invalidates the irrelevance proposition of inflation.

Section 2 provides for the empirical results. First, descriptive statistics are rehearsed (subsection 1). Unconstrained and constrained models are then estimated in the following three subsections. Unconstrained models estimate both an individual intercept and an individual inflation impact (subsection 2.2). These models tackle regressions with core inflation (subsection 2.2.1), and with CPI inflation (subsection 2.2.2). Subsection 2 includes also regressions with real stock returns determined with core inflation and CPI inflation (subsection 2.2.3). More constrained models estimate an individual intercept and a common inflation impact (subsection 2.3.1). Totally constrained models estimate a common intercept and a common inflation impact (subsection 2.3.2). These constrained models are enriched with a system analysis (subsection 2.3) and a panel least squares (subsection 2.4).

\section{Empirical Results}

\subsection{Descriptive Statistics}

There are 30 stocks in the Dow Jones Industrial Index, and adding to them the S\&P 500 stock market index, we get a total of 31 variables. All descriptive statistics for these 31 variables are tabulated in Table 1. All means and medians in Table 1 are measured with a monthly frequency. This does not imply that these unconditional means and medians are statistically significantly different from zero, although this is what is expected. In order to test for significance, the mean must be divided by its standard error, which is the standard deviation divided by the square root of the sample size. This procedure gives t-statistics but not actual p-values, and hence can be misleading for those estimates which are on the border of significance. An easier method to test for significance is to regress the variable in question upon a constant. The estimate of this constant is provided for the mean value, and the standard error of the constant, the t-statistic and the actual p-value are routinely made available by the statistical software.

Table 1. Monthly descriptive statistics on the log returns of the stocks

\begin{tabular}{cccccccc}
\hline & \multirow{2}{*}{$3 \mathrm{M}$} & \multirow{2}{*}{ APPLE } & $\begin{array}{c}\text { AMERICAN } \\
\text { EXPRESS }\end{array}$ & BOEING & CATERPILLAR & CHEVRON & \multirow{2}{*}{ CISCO } \\
& & & & & & \\
\hline Mean & 0.007395 & 0.013029 & 0.008144 & 0.009083 & 0.006629 & 0.005667 & 0.018701 \\
Median & 0.010992 & 0.016669 & 0.012447 & 0.014721 & 0.010382 & 0.007646 & 0.019468 \\
Maximum & 0.229343 & 0.373514 & 0.615364 & 0.395571 & 0.337467 & 0.309712 & 0.336472 \\
Minimum & -0.326251 & -0.860410 & -0.396467 & -0.424194 & -0.444820 & -0.195574 & -0.457687 \\
Std. Dev. & 0.056995 & 0.134680 & 0.084928 & 0.083527 & 0.089407 & 0.062209 & 0.108045 \\
Skewness & -0.449865 & -0.884351 & -0.096330 & -0.412067 & -0.618593 & 0.054709 & -0.403561 \\
Kurtosis & 5.941994 & 7.101259 & 10.49813 & 5.587939 & 5.741843 & 4.534519 & 4.789962 \\
Probability & 0.000000 & 0.000000 & 0.000000 & 0.000000 & 0.000000 & 0.000000 & 0.000000 \\
Observations & 467 & 458 & 467 & 467 & 466 & 467 & 348 \\
\hline
\end{tabular}




\begin{tabular}{cccccccc}
\hline COCA-COLA & DISNEY & $\begin{array}{c}\text { MC } \\
\text { DONALD'S }\end{array}$ & DOWDUPONT & EXXON & HOMEDEPOT & IBM & INTEL \\
\hline 0.008971 & 0.010093 & 0.011099 & 0.005356 & 0.006560 & 0.018312 & 0.004968 & 0.010974 \\
0.009997 & 0.013110 & 0.013767 & 0.007241 & 0.004015 & 0.018093 & 0.004138 & 0.012903 \\
0.201349 & 0.285252 & 0.167692 & 0.273958 & 0.204522 & 0.287682 & 0.302914 & 0.390198 \\
-0.215152 & -0.338672 & -0.296701 & -0.277088 & -0.153459 & -0.446287 & -0.303834 & -0.588749 \\
0.058340 & 0.078365 & 0.059919 & 0.071166 & 0.048783 & 0.090569 & 0.072918 & 0.107354 \\
-0.365335 & -0.449337 & -0.486033 & -0.246662 & 0.042258 & -0.614711 & -0.213839 & -0.614696 \\
4.485450 & 5.129728 & 4.379889 & 4.310305 & 4.000210 & 5.440435 & 5.104586 & 5.739068 \\
0.000000 & 0.000000 & 0.000000 & 0.000000 & 0.000055 & 0.000000 & 0.000000 & 0.000000 \\
467 & 467 & 467 & 467 & 467 & 449 & 467 & 467 \\
\hline
\end{tabular}

\begin{tabular}{cccccccc}
\hline $\begin{array}{c}\text { JOHNSON \& } \\
\text { JOHNSON }\end{array}$ & WALMART & MERCK & $\begin{array}{c}\text { MORGAN } \\
\text { STANLEY }\end{array}$ & NIKE & PFIZER & $\begin{array}{c}\text { PROCTER \& } \\
\text { GAMBLE }\end{array}$ & SACHS \\
\hline 0.009560 & 0.014202 & 0.008227 & 0.006286 & 0.013839 & 0.008503 & 0.008209 & 0.004175 \\
0.011102 & 0.012917 & 0.010419 & 0.006873 & 0.017962 & 0.010161 & 0.009633 & 0.012531 \\
0.171894 & 0.234576 & 0.205114 & 0.275961 & 0.336472 & 0.235722 & 0.220590 & 0.271697 \\
-0.203048 & -0.315551 & -0.309488 & -0.424997 & -0.471763 & -0.277355 & -0.437155 & -0.324822 \\
0.057285 & 0.068268 & 0.068845 & 0.093164 & 0.097548 & 0.066011 & 0.056741 & 0.092585 \\
-0.236446 & -0.274657 & -0.435571 & -0.751364 & -0.591939 & -0.198433 & -1.156042 & -0.127962 \\
3.780970 & 4.286700 & 4.104742 & 5.504433 & 5.661283 & 3.703555 & 11.01502 & 3.794280 \\
0.000301 & 0.000000 & 0.000000 & 0.000000 & 0.000000 & 0.001750 & 0.000000 & 0.032117 \\
467 & 467 & 467 & 467 & 458 & 467 & 467 & 237 \\
\hline
\end{tabular}

\begin{tabular}{cccccccc}
\hline & & & UNITED & UNITED & & \\
MICROSOFT & S\&P 500 & TRAVELERS & HEALTH & TECHNOLOGIES & VISA & VERIZON & WBA \\
\hline 0.017696 & 0.007022 & 0.007313 & 0.018349 & 0.008278 & 0.015283 & 0.004915 & 0.012126 \\
0.020203 & 0.011000 & 0.012254 & 0.026348 & 0.012567 & 0.023002 & 0.006314 & 0.011279 \\
0.385662 & 0.123780 & 0.421716 & 0.510826 & 0.219894 & 0.155588 & 0.319193 & 0.362115 \\
-0.420640 & -0.245428 & -0.299343 & -0.459532 & -0.497127 & -0.219714 & -0.235693 & -0.265179 \\
0.094086 & 0.042932 & 0.070721 & 0.105486 & 0.071672 & 0.059023 & 0.061294 & 0.077633 \\
0.065894 & -0.915927 & 0.149803 & -0.849067 & -1.289850 & -0.830125 & 0.088940 & 0.126868 \\
5.037830 & 6.393597 & 6.710709 & 7.731030 & 10.14620 & 5.378998 & 5.072563 & 4.097775 \\
68.63320 & 289.3881 & 269.6755 & 433.7383 & 1123.195 & 45.93767 & 76.26615 & 24.70218 \\
0.000000 & 0.000000 & 0.000000 & 0.000000 & 0.000000 & 0.000000 & 0.000000 & 0.000004 \\
395 & 467 & 467 & 412 & 467 & 131 & 423 & 467 \\
\hline
\end{tabular}

Source: Investing.com

The first rows in Table 1 give the unconditional means. Column 6 in Table 2 gives the t-statistics, and next to it, column 7, gives the actual p-values. Contrary to expectations not all t-tests on the mean are statistically significant. There are 6 stocks, out of 31, that have an unconditional mean which is not statistically significant. This is surprising, because the absence of drift implies that there is, on average, no positive return to a given stock. The marginal significance level selected is a two-tailed 5\%. It must be mentioned that all p-values computed in this paper are two-sided. Hence a $5 \%$ two-tailed marginal level is in fact a $2.5 \%$ one-sided marginal level. It is no surprise that the 
means that are no different from zero are the lowest ones, except for the mean return of the JB Morgan Chase, which is not big, but which is characterized by a relatively high standard deviation, hence a high standard error, hence a low t-statistic. In other terms the coefficient of variation, which is the ratio of the standard deviation to the mean is unfavorable to the stock. Cisco Systems ranks first in mean returns. Its annualized yield is $22.44 \%$, which is substantial. The average return on Goldman Sachs ranks lowest. Its annualized yield is $0.05 \%$, or 5 basis points, which is a poor average performance. But, it is statistically insignificant. The maximum return, selected across all 31 stocks, is $61.536 \%$, and belongs to American Express. We remind the reader that this figure is monthly! The minimum return, across all stocks, is $-86.040 \%$, which is again a monthly figure, and belongs to Apple. The highest range, between the maximum and the minimum, is for Apple. The range can be interpreted as a measure of dispersion. A better measure of dispersion is the standard deviation. The lowest standard deviation, an annualized $14.87 \%$, is for the S\&P 500. This is as expected because this index is a portfolio of 500 firms that are imperfectly correlated among each other. The rank that is just above the S\&P 500 is for Exxon, with an annualized 16.90\%. The stock with the highest standard deviation is for Apple, with an annualized standard deviation of $46.65 \%$. It seems that Apple has its own peculiarities. Cisco Systems ranks second in standard deviations. We have already noticed that Cisco Systems has the highest mean return. Hence, both the average is the highest and the standard deviation is the next highest. It seems that the return is compensating for the standalone risk. The reader is reminded that annualized means are obtained by multiplying the monthly means by 12 , while the annualized standard deviations are obtained by multiplying the monthly standard deviations by the square root of 12 . The reason why so many stocks, six out of 31 , have shown insignificant average returns is maybe due to the fact that the individual stocks contain a lot of noise which may blur the statistics of the means, and render inferences more difficult.

One final remark is that all stocks fail the Jarque/Bera normality test of Jarque and Bera (1980, 1987). The closest stock for normality is Goldman Sachs, which has an actual p-value of 0.03212 . 
Table 2. Characteristics of the Dow stocks

\begin{tabular}{|c|c|c|c|c|c|c|}
\hline stock & Sample & beta & $\begin{array}{l}\text { Standard } \\
\text { error of } \\
\text { beta }\end{array}$ & $\begin{array}{l}\text { t-stat on } \\
\text { beta }=1\end{array}$ & $\begin{array}{c}\text { t-stat on the } \\
\text { mean }=0\end{array}$ & $\begin{array}{l}\text { p-value of } \\
\text { t-stat on the } \\
\text { mean }\end{array}$ \\
\hline $3 \mathrm{M}$ & 1980:4-2019:3 & 0.805169 & 0.048950 & -3.9802 & 2.803827 & 0.0053 \\
\hline APPLE & 1981:1-2019:3 & 1.353994 & 0.132680 & 2.6680 & 2.070309 & 0.0390 \\
\hline $\begin{array}{l}\text { AMERICAN } \\
\text { EXPRESS }\end{array}$ & 1980:4-2019:3 & 1.365564 & 0.066374 & 5.5076 & 2.072260 & 0.0388 \\
\hline BOEING & 1980:4-2019:3 & 1.074892 & 0.075205 & 0.9958 & 2.349957 & 0.0192 \\
\hline CATERPILLAR & 1980:5-2019:3 & 1.267872 & 0.076672 & 3.4937 & 1.600593 & 0.1101 \\
\hline CHEVRON & 1980:4-2019:3 & 0.780083 & 0.056628 & -3.8835 & 1.968657 & 0.0496 \\
\hline CISCO SYSTEMS & 1990:3-2019:3 & 1.566458 & 0.112266 & 5.0457 & 3.228818 & 0.0014 \\
\hline COCA-COLA & 1980:4-2019:3 & 0.642833 & 0.055521 & -6.4330 & 3.323001 & 0.0010 \\
\hline WALT DISNEY & 1980:4-2019:3 & 1.138413 & 0.066169 & 2.0918 & 2.783159 & 0.0056 \\
\hline MC DONALD'S & 1980:4-2019:3 & 0.756666 & 0.054386 & -4.4742 & 4.003013 & 0.0001 \\
\hline DOWDUPONT & 1980:4-2019:3 & 1.130511 & 0.056222 & 2.3214 & 1.626369 & 0.1045 \\
\hline EXXONMOBIL & 1980:4-2019:3 & 0.624393 & 0.044026 & -8.5315 & 2.905884 & 0.0038 \\
\hline THE HOME DEPOT & 1981:10-2019:3 & 1.084347 & 0.085444 & 0.9872 & 4.284273 & 0.0000 \\
\hline IBM & 1980:4-2019:3 & 0.946663 & 0.065396 & -0.8387 & 1.472241 & 0.1416 \\
\hline INTEL & 1980:4-2019:3 & 1.450364 & 0.094464 & 4.7676 & 2.209139 & 0.0277 \\
\hline $\begin{array}{l}\text { JOHNSON \& } \\
\text { JOHNSON }\end{array}$ & 1980:4-2019:3 & 0.716280 & 0.052207 & -5.4345 & 3.606550 & 0.0003 \\
\hline WALMART & 1980:4-2019:3 & 0.796903 & 0.063814 & -3.0563 & 4.495585 & 0.0000 \\
\hline $\begin{array}{l}\text { MERCK \& } \\
\text { COMPANY }\end{array}$ & 1980:4-2019:3 & 0.719819 & 0.066452 & -4.2163 & 2.582437 & 0.0101 \\
\hline $\begin{array}{l}\text { JPMORGAN } \\
\text { CHASE \& CO. }\end{array}$ & 1980:4-2019:3 & 1.309978 & 0.080230 & 3.8636 & 1.457987 & 0.1455 \\
\hline NIKE & 1981:1-2019:3 & 1.055535 & 0.094344 & 0.5886 & 3.036234 & 0.0025 \\
\hline PFIZER & 1980:4-2019:3 & 0.843139 & 0.059628 & -2.7967 & 2.783711 & 0.0056 \\
\hline $\begin{array}{l}\text { PROCTER \& } \\
\text { GAMBLE }\end{array}$ & 1980:4-2019:3 & 0.532859 & 0.056088 & -8.3287 & 3.126647 & 0.0019 \\
\hline GOLDMAN SACHS & 1996:6-2019:3 & 1.493719 & 0.104029 & 4.7460 & 0.694135 & 0.4883 \\
\hline MICROSOFT & 1986:4-2019:3 & 1.239957 & 0.089320 & 2.6892 & 3.738079 & 0.0002 \\
\hline TRAVELERS & 1980:4-2019:3 & 0.804757 & 0.066656 & -2.9291 & 2.234704 & 0.0259 \\
\hline UNITEDHEALTH & 1984:11-2019:3 & 1.015632 & 0.109614 & 0.1426 & 3.530735 & 0.0005 \\
\hline $\begin{array}{c}\text { UNITED } \\
\text { TECHNOLOGIES }\end{array}$ & 1980:4-2019:3 & 1.212313 & 0.053226 & 3.9889 & 2.495936 & 0.0129 \\
\hline VISA & 2008:4-2019:3 & 0.771078 & 0.096091 & -2.3823 & 2.963581 & 0.0036 \\
\hline VERIZON & $1983: 12-2019: 3$ & 0.642151 & 0.061795 & -5.7909 & 1.649108 & 0.0999 \\
\hline $\begin{array}{c}\text { WALGREENS } \\
\text { BOOTS ALLIANCE }\end{array}$ & 1980:4-2019:3 & 0.971208 & 0.070736 & -0.4070 & 3.375325 & 0.0008 \\
\hline
\end{tabular}

Notes: columns 3 and 4 give the estimates of the betas in the market model regressions, and their standard errors. All coefficients are highly significant, with actual p-values of 0.0000 . Column 5 computes the t-statistic for the 
hypothesis that the beta is +1 . Column 6 gives the t-statistics for the hypothesis that the mean of the log relatives is zero, with its actual p-value next to it, in column 7.

Column 3 in Table 2 records the estimate of the beta coefficient, or systematic risk, by running the market model on all stocks. The market model is a regression of a stock return on the return of the S\&P 500. Column 4 records the standard error of the beta from which a hypothesis test is undertaken in column 5 . The null hypothesis that is tested in column 5 is whether the estimates of the beta are statistically insignificantly different from +1 . Before carrying out the test we draw the attention of the reader that the number of stocks that has betas higher than 1 is equal to the number of stocks with betas that are lower than +1 , i.e. $15 / 15$. The t-tests on the betas show that six out of the 30 stocks have betas statistically insignificantly different from +1 . The number of betas, that are statistically higher than +1 , is eleven, and the number of betas that are statistically less than one is 13 . The highest beta is for 1.5664 , and is for CISCO Systems, and the lowest is for Procter and Gamble and equals 0.5328. This means that CISCO has the highest systematic risk, and one of the highest standalone risks. These findings give us confidence that there is no, or little, selection bias, and subsequently that the selection of the Dow stocks is indeed representative of the universe of stocks, except probably for size, and survival.

\subsection{Unconstrained Models}

\subsubsection{Unconstrained Models with Core Inflation}

In Table 3 are presented parts of the results for the regressions of individual stock returns against core inflation. Only the slopes on the core inflation and its p-values are reported. Core inflation is measured as the Consumer Price Index but without the prices of energy and food. It is considered as the ideal indicator of inflation for monetary policy. As examples are the frequent pronouncements of the governor of the European Central Bank. The regressions at stake are said to be unconstrained. Each individual stock return has its own estimates of intercept and slope. Three econometric procedures are implemented: Ordinary Least Squares (OLS), Seemingly Unrelated Regressions (SUR) and Three-Stage Least Squares (3SLS). OLS estimation is conducted separately for each one of the stock return equation. SUR takes into consideration cross equation relations, and 3SLS does the same, but relies upon instrumental variables (IV). The chosen IV variables are everywhere the lagged values of the S\&P 500 stock market return, of the core inflation and the CPI inflation and the lagged change in the baa bond yield.

Table 3. System regression results with the core inflation rate as an independent variable and the stock log relative as the dependent variable. The intercept is not tabulated. OLS stands for ordinary least squares, SUR for seemingly unrelated regressions, and 3SLS for 3-stage least squares

\begin{tabular}{ccccccc}
\hline \multirow{2}{*}{ STOCK } & \multicolumn{2}{c}{ OLS } & \multicolumn{2}{c}{ SUR } & \multicolumn{2}{c}{ 3SLS } \\
\cline { 2 - 7 } 3M & estimate & p-value & estimate & p-value & estimate & p-value \\
APPLE & -0.296046 & 0.8551 & -0.413090 & 0.7844 & -0.205226 & 0.9355 \\
& & & & & & \\
AMERICAN EXPRESS & -1.984842 & 0.6480 & -2.422845 & 0.5430 & -5.997030 & 0.4352 \\
BOEING & 0.419236 & 0.8622 & 0.104415 & 0.9617 & -1.749984 & 0.6416 \\
& & & & & & \\
CATERPILLAR & -1.968013 & 0.4072 & -2.202324 & 0.3213 & -3.578162 & 0.3351 \\
CHEVRON & 0.552043 & 0.8295 & 0.478611 & 0.8404 & -2.271677 & 0.5670 \\
& & & & & & \\
CISCO SYSTEMS & 1.105860 & 0.5319 & 0.934361 & 0.5805 & -0.488847 & 0.8602 \\
COCA-COLA & 10.60803 & 0.0626 & 9.214009 & 0.0603 & 9.086964 & 0.6150
\end{tabular}

WALT DISNEY 
Vol. 9, No. 1; 2020

\begin{tabular}{|c|c|c|c|c|c|c|}
\hline & -0.028287 & 0.9899 & -0.321840 & 0.8739 & 1.540308 & 0.6574 \\
\hline MC DONALD'S & 0.131320 & 0.9386 & -0.044718 & 0.9772 & -0.765118 & 0.7734 \\
\hline DOWDUPONT & 1.851339 & 0.3601 & 1.661020 & 0.3666 & -0.641014 & 0.8388 \\
\hline EXXONMOBIL & 1.195753 & 0.3885 & 1.016116 & 0.4411 & -0.471474 & 0.8284 \\
\hline THE HOME DEPOT & 9.125573 & 0.0038 & 9.136169 & 0.0011 & 2.504074 & 0.7014 \\
\hline IBM & 0.231382 & 0.9112 & -0.021014 & 0.9911 & 2.699418 & 0.4032 \\
\hline INTEL & 0.928068 & 0.7612 & 0.610098 & 0.8189 & 1.819697 & 0.6993 \\
\hline JOHNSON \& JOHNSON & 1.070209 & 0.5112 & 0.915519 & 0.5468 & -0.043373 & 0.9864 \\
\hline WALMART & 6.090416 & 0.0015 & 5.968143 & 0.0006 & 5.587110 & 0.0630 \\
\hline cMERCK \& COMPANY & 0.949257 & 0.6278 & 0.708115 & 0.7015 & -3.147141 & 0.3067 \\
\hline JPMORGAN CHASE \& CO. & 2.794646 & 0.2911 & 2.414076 & 0.3157 & -1.390367 & 0.7352 \\
\hline NIKE & 3.515031 & 0.2638 & 3.713059 & 0.2009 & 1.001464 & 0.8577 \\
\hline PFIZER & 1.256817 & 0.5031 & 1.051811 & 0.5460 & -1.440852 & 0.6235 \\
\hline PROCTER \& GAMBLE & -1.160683 & 0.4719 & -1.204781 & 0.4389 & -3.218682 & 0.2033 \\
\hline GOLDMAN SACHS & 15.40495 & 0.0126 & 9.850189 & 0.0752 & 33.16165 & 0.0646 \\
\hline MICROSOFT & 10.08459 & 0.0146 & 8.569307 & 0.0144 & 22.53787 & 0.0304 \\
\hline TRAVELERS & 0.272030 & 0.8924 & 0.091700 & 0.9614 & -2.596874 & 0.4107 \\
\hline UNITEDHEALTH & 8.784724 & 0.0450 & 7.373200 & 0.0683 & -6.672746 & 0.5469 \\
\hline UNITED TECHNOLOGIES & -0.872697 & 0.6686 & -1.115521 & 0.5364 & 0.564504 & 0.8589 \\
\hline VISA & 14.44652 & 0.0372 & 9.085391 & 0.1749 & 10.91932 & 0.5730 \\
\hline VERIZON & 1.909871 & 0.4379 & 0.724061 & 0.7450 & -7.534819 & 0.2006 \\
\hline WALGREENS BOOTS ALLIANCE & 2.239154 & 0.3101 & 1.996501 & 0.3291 & 3.668689 & 0.2882 \\
\hline S\&P 500 & 1.310629 & 0.2826 & 1.044974 & 0.2681 & -0.904275 & 0.6276 \\
\hline
\end{tabular}


Using OLS, six stocks out of 31 produce a significant effect of core inflation on the specific or the individual log return. The marginal significance level is set as a two-tailed 5\%. And the estimates of the impact are positive for these six stocks. All six estimates produce impact values that are high and implausible. The minimum impact is 6.090. This means that a $1 \%$ increase in the inflation rate produces around a $6 \%$ effect upon stock returns. Moreover, since the OLS estimation ignores and omits cross-equation information, it is not an appropriate mode for the results. However, it reveals what will a simple naïve and intuitive approach obtains by an unsophisticated investor. Using SUR, three out of 31 inflation slope coefficients are statistically significant at the 5\% marginal significance level. These three are part of the list of stocks that had a significant impact using OLS, and take implausible values: 9.136 (Home Depot), 5.968 (Walmart), and 8.569 (Microsoft). Hence all three coefficients take positive values. Using 3SLS only one stock, Microsoft, is impacted significantly by inflation. And this stock is part of the lists using OLS and SUR. A disturbing feature of Microsoft is that the inflation impact is 22.538, which is too high to be plausible. It is not clear why a technology stock, like Microsoft, is that sensitive to inflation shocks. As a count, in the results of 3SLS, 18 regressions produce a negative inflation impact and 12 regressions produce positive estimates. And it is not the place here to discuss and judge which econometric procedure is better between SUR and 3SLS, but the evidence so far is strong: inflation is irrelevant to individual stock returns, as most stocks, at least 28 , and at most 30 , do not reveal any statistically significant impacts of inflation.

\subsubsection{Unconstrained Models with CPI Inflation}

Using OLS, seven stocks out of 31 produce a significant effect of CPI inflation on the specific or the individual $\log$ returns (Table 4). As above, the marginal significance level is set at a two-tailed 5\%. And the estimates of the impact of inflation are positive for these seven stocks. However, all seven estimates produce impact values that are high and implausible. These range between 1.7801 and 8.8379. An unsophisticated and naïve investor would conclude that inflation has a significant impact for each one of these seven stocks while in fact the relation is spurious. It is true that by using SUR, six out of 31 inflation slope coefficients are still statistically significant at the 5\% marginal significance level. These six are part of the list of stocks that had a significant impact using OLS, and they also take implausible values between 1.400 and 7.172. The only stock equation that drops out from the OLS list is DOW DUPONT. All seven coefficients take positive values. Using 3SLS only one stock, Goldman Sachs is impacted significantly by CPI inflation. And this stock is part of the lists using OLS and SUR. A reassuring note, for an investor looking for irrelevance is Microsoft which drops out from the three lists of significance (OLS, SUR, and 3SLS). As a count, in the results of 3SLS, 20 regressions produce a negative and insignificant inflation impact and 10 regressions produce positive and insignificant estimates. Hence a 3SLS specification produces a vast and complete support for inflation irrelevance.

Table 4. System regression results with the CPI inflation rate as an independent variable and the stock log relative as the dependent variable. The intercept is not tabulated

\begin{tabular}{ccccccc}
\hline \multirow{2}{*}{ STOCK } & \multicolumn{2}{c}{ OLS } & \multicolumn{2}{c}{ SUR } & \multicolumn{2}{c}{ 3SLS } \\
\cline { 2 - 7 } 3M & estimate & p-value & estimate & p-value & estimate & p-value \\
APPLE & -0.812445 & 0.3956 & -1.013077 & 0.2661 & -1.151680 & 0.5247 \\
& 0.560590 & 0.8146 & -0.245427 & 0.9137 & -0.350039 & 0.9416 \\
AMERICAN EXPRESS & 0.729115 & 0.6091 & 0.269362 & 0.8397 & -0.392209 & 0.8843 \\
BOEING & 0.351235 & 0.8022 & 0.057257 & 0.9661 & -4.443409 & 0.0986 \\
CATERPILLAR & 3.365944 & 0.0253 & 3.064935 & 0.0321 & -1.142836 & 0.6884 \\
& & & & & & \\
CHEVRON & 4.851857 & 0.0000 & 4.664151 & 0.0000 & 0.330421 & 0.8672 \\
& & & & & & \\
CISCO SYSTEMS & 3.155438 & 0.1632 & 1.157540 & 0.5762 & 2.243209 & 0.6452
\end{tabular}

COCA-COLA 


\begin{tabular}{|c|c|c|c|c|c|c|}
\hline & 0.073921 & 0.9398 & -0.111806 & 0.9058 & -0.882738 & 0.6349 \\
\hline WALT DISNEY & 1.773339 & 0.1769 & 1.355833 & 0.2724 & 0.195215 & 0.9374 \\
\hline MC DONALD'S & -0.008682 & 0.9931 & -0.245078 & 0.7971 & -1.889935 & 0.3210 \\
\hline DOWDUPONT & 2.506870 & 0.0351 & 2.170392 & 0.0519 & -0.561401 & 0.8038 \\
\hline EXXONMOBIL & 2.822079 & 0.0005 & 2.658197 & 0.0007 & 0.674884 & 0.6622 \\
\hline THE HOME DEPOT & -1.275283 & 0.4468 & -1.614385 & 0.2980 & -5.414343 & 0.1291 \\
\hline IBM & 1.812144 & 0.1380 & 1.373436 & 0.2330 & 2.293830 & 0.3209 \\
\hline INTEL & 2.097262 & 0.2440 & 1.326841 & 0.4211 & -2.037232 & 0.5497 \\
\hline JOHNSON \& JOHNSON & 0.988777 & 0.3034 & 0.801686 & 0.3832 & -0.466324 & 0.7981 \\
\hline WALMART & -0.562438 & 0.6236 & -0.777216 & 0.4714 & 0.456077 & 0.8335 \\
\hline MERCK \& COMPANY & 0.532827 & 0.6448 & 0.295360 & 0.7908 & -2.419680 & 0.2725 \\
\hline JPMORGAN CHASE \& CO. & 0.469550 & 0.7640 & -0.093456 & 0.9492 & -0.434073 & 0.8832 \\
\hline NIKE & 0.040272 & 0.9814 & -0.092847 & 0.9550 & -1.875448 & 0.5879 \\
\hline PFIZER & 0.556793 & 0.6153 & 0.287051 & 0.7857 & -0.671151 & 0.7491 \\
\hline PROCTER \& GAMBLE & 0.088322 & 0.9261 & -0.006520 & 0.9944 & -2.909302 & 0.1102 \\
\hline GOLDMAN SACHS & 8.837881 & 0.0000 & 7.172126 & 0.0001 & 11.32479 & 0.0072 \\
\hline MICROSOFT & 3.068778 & 0.1024 & 1.480929 & 0.3840 & 5.297325 & 0.1879 \\
\hline TRAVELERS & -1.924197 & 0.1042 & -2.146538 & 0.0592 & -2.358677 & 0.2934 \\
\hline UNITEDHEALTH & 3.451432 & 0.0919 & 2.745650 & 0.1604 & -2.868689 & 0.5164 \\
\hline UNITED TECHNOLOGIES & 1.414063 & 0.2393 & 1.065548 & 0.3392 & -1.192237 & 0.6008 \\
\hline VISA & 5.526979 & 0.0008 & 4.268774 & 0.0083 & 3.518033 & 0.1929 \\
\hline VERIZON & -1.200357 & 0.3125 & -1.702413 & 0.1274 & -2.199439 & 0.3849 \\
\hline WALGREENS BOOTS ALLIANCE & 0.795294 & 0.5416 & 0.520849 & 0.6748 & 2.146910 & 0.3847 \\
\hline S\&P 500 & 1.780061 & 0.0129 & 1.399938 & 0.0215 & -0.174289 & 0.8971 \\
\hline
\end{tabular}




\subsubsection{Models with Real Stock Returns}

Tables 5 and 6 present the regression results of regressing real stock returns, i.e. stock returns minus inflation, over inflation. Table 5 uses core inflation, whereas Table 6 uses CPI inflation. In conformity to our main stance it is expected that the relation be insignificant: inflation is neutral on stock returns, and real stock returns and inflation are independent. There is another expectation, which we will call econometric, and it is the following. If nominal stock returns are immune from inflation, then the real inflation beta, from the real returns regression, should be exactly -1 . However, real inflation betas are never exactly -1 . In such a case the estimate of the real inflation beta is equal to the estimate of the nominal inflation beta minus -1 . This is exactly what we find by comparing OLS estimates in Table 3 and Table 5, and the OLS estimates in Table 4 and Table 6. While the evidence in the literature points to the fact that the real inflation beta is indeed -1 (Azar, 2010), the real inflation beta is indeed significantly different from -1 in this paper. However, these comments apply to OLS estimates only. Estimates from SUR and from 3SLS, which are more informative, need not produce a real inflation beta insignificantly different from -1 . There is no room here to discuss this anomaly, but we promise to take it up in future research.

Table 5. System regression results with the core inflation rate as an independent variable and the real (adjusted for inflation) stock log relative as the dependent variable. The intercept is not tabulated

\begin{tabular}{|c|c|c|c|c|c|c|}
\hline \multirow{2}{*}{ STOCK } & \multicolumn{2}{|c|}{ OLS } & \multicolumn{2}{|c|}{ SUR } & \multicolumn{2}{|c|}{ 3SLS } \\
\hline & estimate & $\mathrm{p}$-value & estimate & p-value & estimate & p-value \\
\hline $3 \mathrm{M}$ & -1.296046 & 0.4241 & -1.413090 & 0.3493 & -1.205226 & 0.6348 \\
\hline APPLE & -2.984842 & 0.4924 & -3.422845 & 0.3902 & -6.997030 & 0.3626 \\
\hline AMERICAN EXPRESS & -0.580764 & 0.8100 & -0.895585 & 0.6804 & -2.749984 & 0.4645 \\
\hline BOEING & -2.968013 & 0.2113 & -3.202324 & 0.1493 & -4.578162 & 0.2175 \\
\hline CATERPILLAR & -0.447957 & 0.8613 & -0.521389 & 0.8263 & -3.271677 & 0.4097 \\
\hline CHEVRON & 0.105860 & 0.9523 & -0.065639 & 0.9690 & -1.488847 & 0.5917 \\
\hline CISCO SYSTEMS & 9.608030 & 0.0917 & 8.214009 & 0.0940 & 8.086964 & 0.6544 \\
\hline COCA-COLA & -1.232181 & 0.4578 & -1.386030 & 0.3771 & -0.763961 & 0.7690 \\
\hline WALT DISNEY & -1.028287 & 0.6446 & -1.321840 & 0.5144 & 0.540308 & 0.8764 \\
\hline MC DONALD'S & -0.868680 & 0.6103 & -1.044718 & 0.5046 & -1.765118 & 0.5065 \\
\hline DOWDUPONT & 0.851339 & 0.6738 & 0.661020 & 0.7194 & -1.641014 & 0.6025 \\
\hline EXXONMOBIL & 0.195753 & 0.8877 & 0.016116 & 0.9903 & -1.471474 & 0.4987 \\
\hline THE HOME DEPOT & 8.125573 & 0.0100 & 8.136169 & 0.0037 & 1.504074 & 0.8179 \\
\hline IBM & -0.768618 & 0.7110 & -1.021014 & 0.5898 & 1.699418 & 0.5987 \\
\hline INTEL & -0.071932 & 0.9812 & -0.389902 & 0.8836 & 0.819697 & 0.8619 \\
\hline JOHNSON \& JOHNSON & 0.070209 & 0.9656 & -0.084481 & 0.9557 & -1.043373 & 0.6825 \\
\hline
\end{tabular}




\begin{tabular}{|c|c|c|c|c|c|c|}
\hline WALMART & 5.090416 & 0.0081 & 4.968143 & 0.0045 & 4.587110 & 0.1269 \\
\hline MERCK \& COMPANY & -0.050743 & 0.9793 & -0.291885 & 0.8745 & -4.147141 & 0.1780 \\
\hline JPMORGAN CHASE \& CO. & 1.794646 & 0.4978 & 1.414076 & 0.5568 & -2.390367 & 0.5609 \\
\hline NIKE & 2.515031 & 0.4239 & 2.713059 & 0.3500 & 0.001464 & 0.9998 \\
\hline PFIZER & 0.256817 & 0.8912 & 0.051811 & 0.9763 & -2.440852 & 0.4056 \\
\hline PROCTER \& GAMBLE & -2.160683 & 0.1805 & -2.204781 & 0.1566 & -4.218682 & 0.0954 \\
\hline GOLDMAN SACHS & 14.40495 & 0.0197 & 8.850189 & 0.1099 & 32.16165 & 0.0731 \\
\hline \multicolumn{7}{|l|}{ MICROSOFT } \\
\hline & 9.084587 & 0.0277 & 7.569307 & 0.0307 & 21.53787 & 0.0386 \\
\hline TRAVELERS & -0.727970 & 0.7175 & -0.908300 & 0.6314 & -3.596874 & 0.2545 \\
\hline UNITEDHEALTH & 7.784724 & 0.0757 & 6.373200 & 0.1151 & -7.672746 & 0.4885 \\
\hline UNITED TECHNOLOGIES & -1.872697 & 0.3583 & -2.115521 & 0.2410 & -0.435496 & 0.8909 \\
\hline VISA & 13.44652 & 0.0525 & 8.085391 & 0.2273 & 9.919318 & 0.6087 \\
\hline VERIZON & 0.909871 & 0.7117 & -0.275939 & 0.9014 & -8.534819 & 0.1472 \\
\hline WALGREENS BOOTS ALLIANCE & 1.239154 & 0.5743 & 0.996501 & 0.6261 & 2.668689 & 0.4398 \\
\hline S\&P 500 & 0.310629 & 0.7990 & 0.044974 & 0.9620 & -1.904275 & 0.3070 \\
\hline
\end{tabular}

Table 6. System regression results with the CPI inflation rate as an independent variable and the real (adjusted for inflation) stock log relative as the dependent variable. The intercept is not tabulated.

\begin{tabular}{ccccccc}
\hline \multirow{2}{*}{ STOCK } & \multicolumn{2}{c}{ OLS } & \multicolumn{2}{c}{ SUR } & \multicolumn{2}{c}{ 3SLS } \\
\cline { 2 - 7 } 3M & estimate & p-value & estimate & p-value & estimate & p-value \\
APPLE & -1.812445 & 0.0581 & -2.013077 & 0.0271 & -2.151680 & 0.2347 \\
& -0.439410 & 0.8541 & -1.245427 & 0.5825 & -1.350039 & 0.7775 \\
AMERICAN EXPRESS & -0.270885 & 0.8493 & -0.730638 & 0.5833 & -1.392209 & 0.6054 \\
BOEING & -0.648765 & 0.6437 & -0.942743 & 0.4835 & -5.443409 & 0.0430 \\
CATERPILLAR & 2.365944 & 0.1159 & 2.064935 & 0.1488 & -2.142836 & 0.4521 \\
CHEVRON & 3.851857 & 0.0002 & 3.664151 & 0.0002 & -0.669579 & 0.7347 \\
CISCO SYSTEMS & 2.155438 & 0.3409 & 0.157540 & 0.9394 & 1.243209 & 0.7986
\end{tabular}




\begin{tabular}{|c|c|c|c|c|c|c|}
\hline COCA-COLA & -0.926079 & 0.3445 & -1.111806 & 0.2393 & -1.882738 & 0.3112 \\
\hline WALT DISNEY & 0.773339 & 0.5560 & 0.355833 & 0.7733 & -0.804785 & 0.7461 \\
\hline MC DONALD'S & -1.008682 & 0.3161 & -1.245078 & 0.1916 & -2.889935 & 0.1291 \\
\hline DOWDUPONT & 1.506870 & 0.2052 & 1.170392 & 0.2945 & -1.561401 & 0.4896 \\
\hline EXXONMOBIL & 1.822079 & 0.0243 & 1.658197 & 0.0339 & -0.325116 & 0.8333 \\
\hline THE HOME DEPOT & -2.275283 & 0.1747 & -2.614385 & 0.0919 & -6.414343 & 0.0722 \\
\hline IBM & 0.812144 & 0.5061 & 0.373436 & 0.7457 & 1.293830 & 0.5756 \\
\hline INTEL & 1.097262 & 0.5421 & 0.326841 & 0.8429 & -3.037232 & 0.3725 \\
\hline JOHNSON \& JOHNSON & -0.011223 & 0.9907 & -0.198314 & 0.8292 & -1.466324 & 0.4213 \\
\hline WALMART & -1.562438 & 0.1728 & -1.777216 & 0.0996 & -0.543923 & 0.8020 \\
\hline MERCK \& COMPANY & -0.467173 & 0.6861 & -0.704640 & 0.5269 & -3.419680 & 0.1210 \\
\hline \multicolumn{7}{|l|}{ JPMORGAN CHASE \& CO. } \\
\hline & 3.0450 & 0.7345 & -1.093456 & 0.4557 & -1.434073 & 0.6274 \\
\hline NIKE & -0.959728 & 0.5794 & -1.092847 & 0.5068 & -2.875448 & 0.4061 \\
\hline PFIZER & -0.443207 & 0.6892 & -0.712949 & 0.4995 & -1.671151 & 0.4257 \\
\hline PROCTER \& GAMBLE & -0.911678 & 0.3386 & -1.006520 & 0.2799 & -3.909302 & 0.0318 \\
\hline GOLDMAN SACHS & 7.837881 & 0.0001 & 6.172126 & 0.0010 & 10.32479 & 0.0143 \\
\hline MICROSOFT & 2.068778 & 0.2709 & 0.480929 & 0.7774 & 4.297325 & 0.2854 \\
\hline TRAVELERS & -2.924197 & 0.0135 & -3.146538 & 0.0057 & -3.358677 & 0.1346 \\
\hline UNITEDHEALTH & 2.451432 & 0.2313 & 1.745650 & 0.3722 & -3.868689 & 0.3815 \\
\hline UNITED TECHNOLOGIES & 0.414063 & 0.7304 & 0.065548 & 0.9531 & -2.192237 & 0.3360 \\
\hline VISA & 4.526979 & 0.0063 & 3.268774 & 0.0434 & 2.518033 & 0.3513 \\
\hline VERIZON & -2.200357 & 0.0642 & -2.702413 & 0.0155 & -3.199439 & 0.2062 \\
\hline WALGREENS BOOTS ALLIANCE & -0.204706 & 0.8752 & -0.479151 & 0.6995 & 1.146910 & 0.6424 \\
\hline S\&P 500 & 0.780061 & 0.2761 & 0.399938 & 0.5113 & -1.174289 & 0.3836 \\
\hline
\end{tabular}


As a count, using the core inflation, and with OLS, three stocks only have an absolute t-statistic that denotes that the real inflation beta is significantly different from -1 (Home Depot, Walmart, and Microsoft). With SUR Microsoft drops out and only 2 have an absolute t-statistic that signifies a departure from an estimate of -1 , and these are Home Depot and Walmart. With 3SLS only one stock produces a real inflation beta that has a coefficient significantly different from -1 and this is Procter and Gamble, and Home Depot, Walmart and Microsoft drop out from the list. A 3SLS specification produces a near perfect support for inflation irrelevance, while a SUR specification produces a very strong support for inflation irrelevance.

The statistics that rely on CPI inflation are less favorable to inflation irrelevance. As a count, with OLS, eleven stocks have an absolute t-statistic significantly different from -1 . We need not repeat that OLS estimates are naïve and unsophisticated. With SUR, VISA drops out from the list and 10 stocks have absolute t-statistics that signify a departure from a coefficient of -1 . With 3SLS only six stocks produce a real inflation beta that has an absolute t-statistic significantly different from -1 . The econometric specifications fare less well for inflation irrelevance. Generally we have obtained that in general CPI inflation produces less support for inflation irrelevance.

In what concerns the real inflation betas, there are two cases, like before, one with core inflation and the other with CPI inflation. With core inflation and OLS, five stocks have real inflation betas that are significantly different from zero, and the rest, i.e. 26 stocks have a real inflation beta that is insignificantly different from zero. With core inflation and SUR 28 stocks produce insignificant real inflation betas, and the rest, i.e. three stocks, produce a statistically significant real inflation beta. Finally, with core inflation and 3SLS, only two stocks have a statistically significant real inflation beta, and these are Procter and Gamble and (again!) Microsoft. This is very strong evidence for inflation irrelevance.

The rest of the evidence, and with CPI inflation, real inflation betas are insignificant for 20 stocks (OLS), 21 stocks (SUR), and 26 stocks (3SLS). This evidence corroborates the trend in previous results. Inflation irrelevance is stronger with core inflation, and much more frequent with 3SLS. However, the general result is still supportive of inflation irrelevance, when inflation betas and real inflation betas are considered. Out of 31 , a minimum number of around $2 / 3^{\text {rd }}$ is supportive of inflation irrelevance, and a maximum number of 30 , out of 31 , are supportive of inflation irrelevance.

\subsection{Constrained Slope Models}

\subsubsection{Different Intercepts, Common Inflation Impact}

Tables 7, 8, 9, and 10 dwell on the constrained model of a constant slope for the inflation variable of all 31 stocks, and unconstrained intercepts. Table 7 is for the estimates for core inflation and nominal stock returns. The three estimates are 1.5646 (OLS), 1.2671 (SUR), and -0.8754 (3SLS), and they carry p-values that fail to reject the null hypothesis of a zero common slope, except for the OLS procedure. The p-values are respectively 0.0004 (OLS), 0.1188 (SUR), and 0.5598 (3SLS). A naïve and unsophisticated investor would erroneously reject the inflation irrelevance if she does not take in consideration cross equation relations.

Two of the other estimates reject the above null. These two estimates are for CPI inflation and nominal stock returns, and they carry actual p-values as follows: 0.0000 (OLS), and 0.0176 (SUR).

The remaining seven estimates are all within reasonable range, the minimum p-value being 0.2010 . One of these seven estimates is for CPI inflation, nominal stock returns, and 3SLS. The following six estimates are evenly divided between core inflation and CPI inflation, and they all cover real stock returns. Again more than $2 / 3^{\text {rd }}$ estimates support inflation irrelevance, and $100 \%$ of real stock returns support the same. For real stock returns there is an additional null hypothesis, which is that the slope be insignificantly different from -1 and 2 out of six support this null. Two of the rejected nulls correspond to OLS estimation. Again, in this situation, a naïve and unsophisticated investor would erroneously reject the inflation irrelevance if she does not take into consideration cross equation relations. 
Table 7. Constrained system regressions results with a common coefficient on the core inflation rate. The log relative of the stocks is the dependent variable. The slope is assumed constant across all regressions, and intercepts vary

\begin{tabular}{|c|c|c|c|c|c|c|}
\hline \multirow{2}{*}{ STOCK } & \multicolumn{2}{|c|}{ OLS } & \multicolumn{2}{|c|}{ SUR } & \multicolumn{2}{|c|}{ 3SLS } \\
\hline & estimate & p-value & estimate & p-value & estimate & p-value \\
\hline $3 \mathrm{M}$ & 0.004005 & 0.2914 & 0.004935 & 0.1272 & 0.009238 & 0.0271 \\
\hline Common slope & 1.564552 & 0.0004 & 1.267131 & 0.1188 & -0.875361 & 0.5598 \\
\hline APPLE & 0.009805 & 0.0102 & 0.011217 & 0.0827 & 0.014877 & 0.0351 \\
\hline AMERICAN EXPRESS & 0.004754 & 0.2104 & 0.005860 & 0.1743 & 0.010033 & 0.0490 \\
\hline BOEING & 0.005693 & 0.1336 & 0.006646 & 0.1209 & 0.011122 & 0.0275 \\
\hline CATERPILLAR & 0.003254 & 0.3916 & 0.004463 & 0.3227 & 0.008518 & 0.1050 \\
\hline CHEVRON & 0.002277 & 0.5485 & 0.003149 & 0.3582 & 0.007496 & 0.0837 \\
\hline CISCO SYSTEMS & 0.016258 & 0.0002 & 0.017620 & 0.0020 & 0.021068 & 0.0009 \\
\hline COCA-COLA & 0.005581 & 0.1415 & 0.006403 & 0.0519 & 0.010848 & 0.0101 \\
\hline WALT DISNEY & 0.006702 & 0.0774 & 0.007745 & 0.0569 & 0.011874 & 0.0147 \\
\hline MC DONALD'S & 0.007709 & 0.0423 & 0.008628 & 0.0103 & 0.012798 & 0.0027 \\
\hline DOWDUPONT & 0.001966 & 0.6045 & 0.003063 & 0.4155 & 0.007095 & 0.1244 \\
\hline EXXONMOBIL & 0.003170 & 0.4037 & 0.003961 & 0.1751 & 0.008352 & 0.0344 \\
\hline THE HOME DEPOT & 0.015214 & 0.0001 & 0.016763 & 0.0003 & 0.020054 & 0.0002 \\
\hline IBM & 0.001578 & 0.6777 & 0.002652 & 0.4876 & 0.006848 & 0.1434 \\
\hline INTEL & 0.007584 & 0.0457 & 0.008885 & 0.0871 & 0.012694 & 0.0324 \\
\hline JOHNSON \& JOHNSON & 0.006170 & 0.1040 & 0.006998 & 0.0315 & 0.011350 & 0.0067 \\
\hline WALMART & 0.010812 & 0.0044 & 0.011829 & 0.0013 & 0.016121 & 0.0004 \\
\hline MERCK \& COMPANY & 0.004837 & 0.2025 & 0.005625 & 0.1284 & 0.010028 & 0.0273 \\
\hline JPMORGAN CHASE \& CO. & 0.002895 & 0.4455 & 0.004076 & 0.3776 & 0.008038 & 0.1361 \\
\hline NIKE & 0.010616 & 0.0054 & 0.011916 & 0.0153 & 0.015728 & 0.0047 \\
\hline PFIZER & 0.005113 & 0.1779 & 0.005979 & 0.0957 & 0.010255 & 0.0213 \\
\hline PROCTER \& GAMBLE & 0.004819 & 0.2042 & 0.005582 & 0.0830 & 0.009930 & 0.0172 \\
\hline GOLDMAN SACHS & 0.001947 & 0.7078 & 0.003993 & 0.4911 & 0.006044 & 0.3469 \\
\hline MICROSOFT & 0.014949 & 0.0002 & 0.016314 & 0.0008 & 0.019707 & 0.0004 \\
\hline TRAVELERS & 0.003923 & 0.3013 & 0.004852 & 0.1982 & 0.009203 & 0.0458 \\
\hline UNITEDHEALTH & 0.015513 & 0.0001 & 0.015881 & 0.0035 & 0.020123 & 0.0008 \\
\hline UNITED TECHNOLOGIES & 0.004888 & 0.1978 & 0.005933 & 0.1183 & 0.010152 & 0.0287 \\
\hline VISA & 0.013274 & 0.0564 & 0.014186 & 0.0059 & 0.016933 & 0.0021 \\
\hline VERIZON & 0.002016 & 0.6093 & 0.002781 & 0.4206 & 0.006836 & 0.1065 \\
\hline $\begin{array}{c}\text { WALGREENS BOOTS } \\
\text { ALLIANCE }\end{array}$ & 0.008735 & 0.0214 & 0.009715 & 0.0166 & 0.013853 & 0.0042 \\
\hline S\&P 500 & 0.003632 & 0.3386 & 0.004647 & 0.0865 & 0.008828 & 0.0201 \\
\hline
\end{tabular}


Table 8. Constrained system regressions results with a common coefficient on the CPI inflation rate. The log relative of the stocks is the dependent variable. The slope is assumed constant across all regressions, and intercepts vary

\begin{tabular}{|c|c|c|c|c|c|c|}
\hline \multirow{2}{*}{ STOCK } & \multicolumn{2}{|c|}{ OLS } & \multicolumn{2}{|c|}{ SUR } & \multicolumn{2}{|c|}{ 3SLS } \\
\hline & estimate & p-value & estimate & p-value & estimate & p-value \\
\hline $3 \mathrm{M}$ & 0.004316 & 0.2461 & 0.004859 & 0.0938 & 0.007422 & 0.0401 \\
\hline Common slope & 1.263246 & 0.0000 & 1.172216 & 0.0176 & -0.029993 & 0.9766 \\
\hline APPLE & 0.010095 & 0.0071 & 0.011197 & 0.0736 & 0.013072 & 0.0526 \\
\hline AMERICAN EXPRESS & 0.005066 & 0.1735 & 0.005816 & 0.1473 & 0.008217 & 0.0770 \\
\hline BOEING & 0.006005 & 0.1066 & 0.006579 & 0.1007 & 0.009306 & 0.0426 \\
\hline CATERPILLAR & 0.003571 & 0.3377 & 0.004403 & 0.2978 & 0.006702 & 0.1645 \\
\hline CHEVRON & 0.002589 & 0.4867 & 0.003068 & 0.3201 & 0.005680 & 0.1349 \\
\hline CISCO SYSTEMS & 0.016225 & 0.0002 & 0.017521 & 0.0015 & 0.019471 & 0.0015 \\
\hline COCA-COLA & 0.005893 & 0.1133 & 0.006335 & 0.0323 & 0.009032 & 0.0137 \\
\hline WALT DISNEY & 0.007014 & 0.0595 & 0.007702 & 0.0400 & 0.010058 & 0.0220 \\
\hline MC DONALD'S & 0.008021 & 0.0311 & 0.008570 & 0.0045 & 0.010982 & 0.0031 \\
\hline DOWDUPONT & 0.002277 & 0.5405 & 0.003003 & 0.3818 & 0.005280 & 0.2000 \\
\hline EXXONMOBIL & 0.003481 & 0.3495 & 0.003880 & 0.1272 & 0.006536 & 0.0510 \\
\hline THE HOME DEPOT & 0.015499 & 0.0000 & 0.016722 & 0.0001 & 0.018273 & 0.0002 \\
\hline IBM & 0.001889 & 0.6117 & 0.002608 & 0.4562 & 0.005032 & 0.2294 \\
\hline INTEL & 0.007896 & 0.0339 & 0.008899 & 0.0699 & 0.010878 & 0.0501 \\
\hline JOHNSON \& JOHNSON & 0.006482 & 0.0816 & 0.006933 & 0.0170 & 0.009535 & 0.0086 \\
\hline WALMART & 0.011124 & 0.0028 & 0.011774 & 0.0005 & 0.014305 & 0.0004 \\
\hline MERCK \& COMPANY & 0.005149 & 0.1665 & 0.005570 & 0.1008 & 0.008212 & 0.0418 \\
\hline JPMORGAN CHASE \& CO. & 0.003207 & 0.3888 & 0.004043 & 0.3519 & 0.006222 & 0.2108 \\
\hline NIKE & 0.010905 & 0.0037 & 0.011868 & 0.0110 & 0.013928 & 0.0070 \\
\hline PFIZER & 0.005425 & 0.1449 & 0.005927 & 0.0694 & 0.008439 & 0.0318 \\
\hline PROCTER \& GAMBLE & 0.005131 & 0.1680 & 0.005500 & 0.0577 & 0.008115 & 0.0244 \\
\hline GOLDMAN SACHS & 0.001910 & 0.7120 & 0.003750 & 0.5065 & 0.004639 & 0.4602 \\
\hline MICROSOFT & 0.014978 & 0.0002 & 0.016258 & 0.0004 & 0.017991 & 0.0006 \\
\hline TRAVELERS & 0.004235 & 0.2551 & 0.004783 & 0.1701 & 0.007387 & 0.0718 \\
\hline UNITEDHEALTH & 0.015643 & 0.0001 & 0.015790 & 0.0026 & 0.018416 & 0.0012 \\
\hline UNITED TECHNOLOGIES & 0.005200 & 0.1624 & 0.005879 & 0.0893 & 0.008336 & 0.0441 \\
\hline VISA & 0.013648 & 0.0492 & 0.014188 & 0.0046 & 0.015772 & 0.0031 \\
\hline VERIZON & 0.002182 & 0.5754 & 0.002694 & 0.3957 & 0.005131 & 0.1757 \\
\hline $\begin{array}{c}\text { WALGREENS BOOTS } \\
\text { ALLIANCE }\end{array}$ & 0.009047 & 0.0151 & 0.009659 & 0.0102 & 0.012037 & 0.0058 \\
\hline S\&P 500 & 0.003944 & 0.2893 & 0.004595 & 0.0401 & 0.007012 & 0.0271 \\
\hline
\end{tabular}


Table 9. Constrained system regressions results with a common coefficient on the core inflation rate. The log relative of the stocks, adjusted for inflation, is the dependent variable. The slope is assumed constant across all regressions, and intercepts vary

\begin{tabular}{|c|c|c|c|c|c|c|}
\hline \multirow[t]{2}{*}{ STOCK } & \multicolumn{2}{|c|}{ OLS } & \multicolumn{2}{|c|}{$\begin{array}{l}\text { SUR } \\
\end{array}$} & \multicolumn{2}{|c|}{3 SLS } \\
\hline & estimate & p-value & estimate & p-value & estimate & p-value \\
\hline $3 \mathrm{M}$ & 0.004005 & 0.2914 & 0.004935 & 0.1272 & 0.009238 & 0.0271 \\
\hline Common slope & 0.564552 & 0.2010 & 0.267131 & 0.7423 & -1.875361 & 0.2116 \\
\hline APPLE & 0.009805 & 0.0102 & 0.011217 & 0.0827 & 0.014877 & 0.0351 \\
\hline AMERICAN EXPRESS & 0.004754 & 0.2104 & 0.005860 & 0.1743 & 0.010033 & 0.0490 \\
\hline BOEING & 0.005693 & 0.1336 & 0.006646 & 0.1209 & 0.011122 & 0.0275 \\
\hline CATERPILLAR & 0.003254 & 0.3916 & 0.004463 & 0.3227 & 0.008518 & 0.1050 \\
\hline CHEVRON & 0.002277 & 0.5485 & 0.003149 & 0.3582 & 0.007496 & 0.0837 \\
\hline CISCO SYSTEMS & 0.016258 & 0.0002 & 0.017620 & 0.0020 & 0.021068 & 0.0009 \\
\hline COCA-COLA & 0.005581 & 0.1415 & 0.006403 & 0.0519 & 0.010848 & 0.0101 \\
\hline WALT DISNEY & 0.006702 & 0.0774 & 0.007745 & 0.0569 & 0.011874 & 0.0147 \\
\hline MC DONALD'S & 0.007709 & 0.0423 & 0.008628 & 0.0103 & 0.012798 & 0.0027 \\
\hline DOWDUPONT & 0.001966 & 0.6045 & 0.003063 & 0.4155 & 0.007095 & 0.1244 \\
\hline EXXONMOBIL & 0.003170 & 0.4037 & 0.003961 & 0.1751 & 0.008352 & 0.0344 \\
\hline THE HOME DEPOT & 0.015214 & 0.0001 & 0.016763 & 0.0003 & 0.020054 & 0.0002 \\
\hline IBM & 0.001578 & 0.6777 & 0.002652 & 0.4876 & 0.006848 & 0.1434 \\
\hline INTEL & 0.007584 & 0.0457 & 0.008885 & 0.0871 & 0.012694 & 0.0324 \\
\hline JOHNSON \& JOHNSON & 0.006170 & 0.1040 & 0.006998 & 0.0315 & 0.011350 & 0.0067 \\
\hline WALMART & 0.010812 & 0.0044 & 0.011829 & 0.0013 & 0.016121 & 0.0004 \\
\hline MERCK \& COMPANY & 0.004837 & 0.2025 & 0.005625 & 0.1284 & 0.010028 & 0.0273 \\
\hline JPMORGAN CHASE \& CO. & 0.002895 & 0.4455 & 0.004076 & 0.3776 & 0.008038 & 0.1361 \\
\hline NIKE & 0.010616 & 0.0054 & 0.011916 & 0.0153 & 0.015728 & 0.0047 \\
\hline PFIZER & 0.005113 & 0.1779 & 0.005979 & 0.0957 & 0.010255 & 0.0213 \\
\hline PROCTER \& GAMBLE & 0.004819 & 0.2042 & 0.005582 & 0.0830 & 0.009930 & 0.0172 \\
\hline GOLDMAN SACHS & 0.001947 & 0.7078 & 0.003993 & 0.4911 & 0.006044 & 0.3469 \\
\hline MICROSOFT & 0.014949 & 0.0002 & 0.016314 & 0.0008 & 0.019707 & 0.0004 \\
\hline TRAVELERS & 0.003923 & 0.3013 & 0.004852 & 0.1982 & 0.009203 & 0.0458 \\
\hline UNITEDHEALTH & 0.015513 & 0.0001 & 0.015881 & 0.0035 & 0.020123 & 0.0008 \\
\hline UNITED TECHNOLOGIES & 0.004888 & 0.1978 & 0.005933 & 0.1183 & 0.010152 & 0.0287 \\
\hline VISA & 0.013274 & 0.0564 & 0.014186 & 0.0059 & 0.016933 & 0.0021 \\
\hline VERIZON & 0.002016 & 0.6093 & 0.002781 & 0.4206 & 0.006836 & 0.1065 \\
\hline $\begin{array}{c}\text { WALGREENS BOOTS } \\
\text { ALLIANCE }\end{array}$ & 0.008735 & 0.0214 & 0.009715 & 0.0166 & 0.013853 & 0.0042 \\
\hline S\&P 500 & 0.003632 & 0.3386 & 0.004647 & 0.0865 & 0.008828 & 0.0201 \\
\hline
\end{tabular}


Table 10. Constrained system regressions results with a common coefficient on the CPI inflation rate. The log relative of the stocks, adjusted for inflation, is the dependent variable. The slope is assumed constant across all regressions, and intercepts vary

\begin{tabular}{|c|c|c|c|c|c|c|}
\hline \multirow[t]{2}{*}{ STOCK } & \multicolumn{2}{|c|}{ OLS } & \multicolumn{2}{|c|}{ SUR } & \multicolumn{2}{|c|}{ 3SLS } \\
\hline & estimate & p-value & estimate & p-value & estimate & p-value \\
\hline $3 \mathrm{M}$ & 0.004316 & 0.2461 & 0.004859 & 0.0938 & 0.007422 & 0.0401 \\
\hline Common slope & 0.263246 & 0.2924 & 0.172216 & 0.7272 & -1.029993 & 0.3131 \\
\hline APPLE & 0.010095 & 0.0071 & 0.011197 & 0.0736 & 0.013072 & 0.0526 \\
\hline AMERICAN EXPRESS & 0.005066 & 0.1735 & 0.005816 & 0.1473 & 0.008217 & 0.0770 \\
\hline BOEING & 0.006005 & 0.1066 & 0.006579 & 0.1007 & 0.009306 & 0.0426 \\
\hline CATERPILLAR & 0.003571 & 0.3377 & 0.004403 & 0.2978 & 0.006702 & 0.1645 \\
\hline CHEVRON & 0.002589 & 0.4867 & 0.003068 & 0.3201 & 0.005680 & 0.1349 \\
\hline CISCO SYSTEMS & 0.016225 & 0.0002 & 0.017521 & 0.0015 & 0.019471 & 0.0015 \\
\hline COCA-COLA & 0.005893 & 0.1133 & 0.006335 & 0.0323 & 0.009032 & 0.0137 \\
\hline WALT DISNEY & 0.007014 & 0.0595 & 0.007702 & 0.0400 & 0.010058 & 0.0220 \\
\hline MC DONALD'S & 0.008021 & 0.0311 & 0.008570 & 0.0045 & 0.010982 & 0.0031 \\
\hline DOWDUPONT & 0.002277 & 0.5405 & 0.003003 & 0.3818 & 0.005280 & 0.2000 \\
\hline EXXONMOBIL & 0.003481 & 0.3495 & 0.003880 & 0.1272 & 0.006536 & 0.0510 \\
\hline THE HOME DEPOT & 0.015499 & 0.0000 & 0.016722 & 0.0001 & 0.018273 & 0.0002 \\
\hline IBM & 0.001889 & 0.6117 & 0.002608 & 0.4562 & 0.005032 & 0.2294 \\
\hline INTEL & 0.007896 & 0.0339 & 0.008899 & 0.0699 & 0.010878 & 0.0501 \\
\hline JOHNSON \& JOHNSON & 0.006482 & 0.0816 & 0.006933 & 0.0170 & 0.009535 & 0.0086 \\
\hline WALMART & 0.011124 & 0.0028 & 0.011774 & 0.0005 & 0.014305 & 0.0004 \\
\hline MERCK \& COMPANY & 0.005149 & 0.1665 & 0.005570 & 0.1008 & 0.008212 & 0.0418 \\
\hline JPMORGAN CHASE \& CO. & 0.003207 & 0.3888 & 0.004043 & 0.3519 & 0.006222 & 0.2108 \\
\hline NIKE & 0.010905 & 0.0037 & 0.011868 & 0.0110 & 0.013928 & 0.0070 \\
\hline PFIZER & 0.005425 & 0.1449 & 0.005927 & 0.0694 & 0.008439 & 0.0318 \\
\hline PROCTER \& GAMBLE & 0.005131 & 0.1680 & 0.005500 & 0.0577 & 0.008115 & 0.0244 \\
\hline GOLDMAN SACHS & 0.001910 & 0.7120 & 0.003750 & 0.5065 & 0.004639 & 0.4602 \\
\hline MICROSOFT & 0.014978 & 0.0002 & 0.016258 & 0.0004 & 0.017991 & 0.0006 \\
\hline TRAVELERS & 0.004235 & 0.2551 & 0.004783 & 0.1701 & 0.007387 & 0.0718 \\
\hline UNITEDHEALTH & 0.015643 & 0.0001 & 0.015790 & 0.0026 & 0.018416 & 0.0012 \\
\hline UNITED TECHNOLOGIES & 0.005200 & 0.1624 & 0.005879 & 0.0893 & 0.008336 & 0.0441 \\
\hline VISA & 0.013648 & 0.0492 & 0.014188 & 0.0046 & 0.015772 & 0.0031 \\
\hline VERIZON & 0.002182 & 0.5754 & 0.002694 & 0.3957 & 0.005131 & 0.1757 \\
\hline $\begin{array}{c}\text { WALGREENS BOOTS } \\
\text { ALLIANCE }\end{array}$ & 0.009047 & 0.0151 & 0.009659 & 0.0102 & 0.012037 & 0.0058 \\
\hline S\&P 500 & 0.003944 & 0.2893 & 0.004595 & 0.0401 & 0.007012 & 0.0271 \\
\hline
\end{tabular}

2.3.2 Totally Constrained Models

Constraining all intercepts to be the same, and all slopes on the inflation variable to be the same, two tables are produced: one for core inflation (Table 11), and the other one for CPI inflation (Table 12). In Table 11, the same result obtains: the estimate with OLS, and with nominal stock returns, has a very low p-value (0.0013), rejecting the null of irrelevance of inflation. Moreover, the inflation beta estimate with OLS, and real stock returns, rejects the null 
of equality to -1 , with a p-value of 0.0010 . All other estimates fail to reject the nulls. For example, with nominal stock returns and both SUR and 3SLS the respective p-values are 0.1510 and 0.3523 . For real stock returns the betas have all relatively high actual p-values: 0.3084 (OLS), 0.7454 (SUR), and 0.1060 (3SLS). Finally the econometric hypothesis fails to be rejected with p-values of 0.1163 (SUR) and 0.3527 (3SLS).

Constraining all intercepts to be the same, all slopes on the inflation variable to be the same, and using CPI inflation, Table 12 is produced. In Table 12, the similar results obtain: the estimate with OLS, and with nominal stock returns, has a very low p-value (0.0000), rejecting the null of irrelevance of inflation. Moreover, the CPI inflation beta estimate with OLS, and real stock returns, rejects the null of equality to -1 , with a p-value of 0.0000 . The CPI inflation beta for nominal stock returns, and SUR estimation has a low p-value (0.0267), rejecting the null of inflation irrelevance. Surprisingly the actual p-value for the econometric hypothesis is also 0.0267. It is not clear why this regularity is found. All other estimates fail to reject the nulls. For example, with nominal stock returns and 3SLS the actual p-value is 0.6856. As above, this p-value is the same as the p-value for the econometric hypothesis. For real stock returns the betas have all relatively high support for inflation irrelevance with actual p-values: 0.3084 (0.3807), 0.8530 (SUR), and 0.1613 (3SLS). Finally the econometric hypothesis fails to be rejected only for the 3SLS procedure with a p-value of 0.6856 . It is to be noted that the inflation betas for real stock returns is exactly equal to the inflation betas for nominal stock returns minus 1 . This regularity will be checked and explained in a later paper that we promise to prepare. Especially interesting is the fact that this regularity did not appear with the corresponding core inflation regressions (see Table 11).

Table 11. Totally constrained system regressions with core inflation as an independent variable

\begin{tabular}{|c|c|c|c|c|c|}
\hline $\begin{array}{l}\text { Econometric } \\
\text { procedure }\end{array}$ & $\begin{array}{l}\text { Dependent } \\
\text { variable }\end{array}$ & Slope $=0$ & $\mathrm{p}$-value & Slope $=-1$ & $\mathrm{p}$-value \\
\hline \multirow[t]{2}{*}{ OLS } & $\begin{array}{l}\text { Nominal } \\
\text { Log return }\end{array}$ & 1.406401 & 0.0013 & & \\
\hline & Real log return & 0.446763 & 0.3084 & 1.446763 & 0.0010 \\
\hline \multirow{2}{*}{$\begin{array}{l}\text { Seemingly } \\
\text { Unrelated } \\
\text { regressions }\end{array}$} & $\begin{array}{l}\text { Nominal log } \\
\text { return }\end{array}$ & 1.153903 & 0.1510 & & \\
\hline & Real log return & 0.260680 & 0.7454 & 1.260680 & 0.1163 \\
\hline \multirow[t]{2}{*}{ 3SLS } & $\begin{array}{l}\text { Nominal log } \\
\text { return }\end{array}$ & -1.356020 & 0.3523 & & \\
\hline & Real log return & -2.352341 & 0.1060 & -1.352341 & 0.3527 \\
\hline
\end{tabular}

Table 12. Totally constrained system regressions with CPI inflation as an independent variable

\begin{tabular}{cccccc}
\hline $\begin{array}{c}\text { Econometric } \\
\text { procedure }\end{array}$ & $\begin{array}{c}\text { Dependent } \\
\text { variable }\end{array}$ & Slope & p-value & Slope=-1 & p-value \\
\hline \multirow{2}{*}{ OLS } & $\begin{array}{c}\text { Nominal } \\
\text { Log return }\end{array}$ & 1.218807 & 0.0000 & & \\
\cline { 2 - 6 } & Real log return & 0.218807 & 0.3807 & 1.218807 & 0.0000 \\
\hline $\begin{array}{c}\text { Seemingly } \\
\text { Unrelated } \\
\text { regressions }\end{array}$ & $\begin{array}{c}\text { Nominal log } \\
\text { return }\end{array}$ & 1.091211 & 0.0267 & & \\
\cline { 2 - 6 } & Real log return & 0.091211 & 0.8530 & 1.091211 & 0.0267 \\
\hline \multirow{2}{*}{ 3SLS } & $\begin{array}{c}\text { Nominal log } \\
\text { return }\end{array}$ & -0.406442 & 0.6856 & & \\
\cline { 2 - 6 } & Real log return & -1.406442 & 0.1613 & -0.406442 & 0.6856
\end{tabular}

\subsection{Panel Models}

Table 13 is about panel analysis. The data are transformed to an unbalanced panel. The procedures effectuated are: panel least squares, panel least squares with cross section SUR-standard errors and covariance, panel least squares with White cross section standard errors and covariance, Panel 2SLS (Two-Stage Least Squares), Limited information maximum likelihood (LIML), panel GMM, and Robust least squares. The results of the 2SLS procedure 
are the same as the results of Panel GMM, and therefore one of them will be commented upon. In all other results the estimated inflation beta on nominal stock returns, and the real inflation betas on real stock returns, are linked together. The latter is equal to the former by removing the scalar -1 . Moreover the econometric hypothesis that the real inflation beta is equal to -1 is always the same p-value as the hypothesis for the nominal inflation beta. Panel least squares produces two rejections of the nulls that the inflation beta is 0 and that, additionally, the real inflation beta is also -1. However the real inflation beta fails to achieve statistical significance, which supports inflation irrelevance. All remaining procedures support inflation irrelevance, except for the results of robust least squares, for which the nominal inflation beta is statistically non-zero and the real inflation beta is statistically unequal to -1 . In addition the real inflation beta is statistically different from zero for 2SLS and LIML. All other estimates produce p-values that are much higher than the marginal significance level of 5\%. Out of a total of 42 estimates 31 estimates support the irrelevance of inflation, which is around 74\%. If one removes the OLS and the robust least squares estimates, which do not take into consideration cross section dependencies, the total count is 30 , out of which 28 support irrelevance of inflation, a percentage of $93.33 \%$. Especially noteworthy are the facts that the Panel 2 SLS and the Panel Least Squares with adjustment of standard errors and covariance, to become robust against the presence of serial correlation and heteroscedasticity, support strongly inflation irrelevance.

Table 13. Table for Panel Least Squares (PLS)

\begin{tabular}{|c|c|c|c|c|c|c|}
\hline \multirow{2}{*}{$\begin{array}{l}\text { Econometric } \\
\text { procedure }\end{array}$} & \multirow{2}{*}{$\begin{array}{c}\begin{array}{c}\text { Nominal stock } \\
\text { return }\end{array} \\
\text { (Core inflation) }\end{array}$} & \multicolumn{2}{|c|}{$\begin{array}{l}\text { Real stock return } \\
\text { (core inflation) }\end{array}$} & \multirow{2}{*}{$\begin{array}{c}\text { Nominal } \\
\text { stock return } \\
\begin{array}{c}(\mathrm{CPI} \\
\text { inflation })\end{array} \\
\text { Slope }=0\end{array}$} & \multicolumn{2}{|c|}{$\begin{array}{l}\text { Real stock return } \\
\text { (CPI inflation) }\end{array}$} \\
\hline & & Slope $=0$ & Slope $=-1$ & & Slope $=0$ & Slope $=-1$ \\
\hline \multirow{3}{*}{$\begin{array}{l}\text { Panel Least Squares } \\
\text { (PLS) }\end{array}$} & 1.574671 & 0.574671 & 1.574671 & 1.244331 & 0.244331 & 1.244331 \\
\hline & $(0.0006)$ & $(0.6473)$ & $(0.0006)$ & $(0.0000)$ & $(0.3432)$ & $(0.0000)$ \\
\hline & 1.574671 & 0.574671 & 1.574671 & 1.244331 & 0.244331 & 1.244331 \\
\hline $\begin{array}{l}\text { PLS with cross section } \\
\text { SUR-standard errors } \\
\text { and covariance }\end{array}$ & $(0.2100)$ & $(0.6853)$ & $(0.2100)$ & $(0.0879)$ & $(0.7375)$ & $(0.0879)$ \\
\hline $\begin{array}{l}\text { PLS with cross section } \\
\text { White-standard errors } \\
\text { and covariance }\end{array}$ & $\begin{array}{l}1.574671 \\
(0.2669)\end{array}$ & $\begin{array}{l}0.574671 \\
(0.6473)\end{array}$ & $\begin{array}{l}1.574671 \\
(0.2669)\end{array}$ & $\begin{array}{l}1.244331 \\
(0.2543)\end{array}$ & $\begin{array}{l}0.244331 \\
(0.8229)\end{array}$ & $\begin{array}{l}1.244331 \\
(0.2543)\end{array}$ \\
\hline \multirow[t]{2}{*}{ Panel 2SLS } & 1.140250 & 0.140250 & 1.140250 & -0.08743 & -1.08743 & -0.08743 \\
\hline & $(0.1332)$ & $(0.9466)$ & $(0.1332)$ & $(0.8628)$ & $(0.0316)$ & $(0.8628)$ \\
\hline \multirow[t]{2}{*}{ LIML } & 0.897709 & -0.10229 & 0.897709 & -0.24690 & -1.24690 & -0.24690 \\
\hline & $(0.2298)$ & $(0.8912)$ & $(0.2298)$ & $(0.6233)$ & $(0.0316)$ & $(0.6233)$ \\
\hline \multirow[t]{2}{*}{ Panel GMM } & 1.140250 & 0.140250 & 1.140250 & -0.08743 & -1.08743 & -0.08743 \\
\hline & $(0.1332)$ & $(0.9466)$ & $(0.1332)$ & $(0.8628)$ & $(0.0316)$ & $(0.8628)$ \\
\hline \multirow[t]{2}{*}{ Robust Least Squares } & 0.953074 & -0.04692 & 0.953078 & 0.742915 & -0.25707 & 0.742915 \\
\hline & $(0.0160)$ & $(0.9056)$ & $(0.0160)$ & $(0.0010)$ & $(0.2531)$ & $(0.0010)$ \\
\hline
\end{tabular}

Notes: All PLS are in cross section fixed dummy variables. 2SLS stands for Two-Stage Least Squares. LIML stands for Limited Information Maximum Likelihood. GMM stands for Generalized Method of Moments.

\section{Conclusion}

Economists are divided between those who posit that inflation impacts negatively nominal and real stock returns, and those who believe that stock indexes and the price level are cointegrated in a long run positive relation. The former 
mainly invoke market inefficiencies and sophisticated transmission mechanisms, while the latter invoke just the principle that stock returns are a hedge against inflation. The two relations enter and are reconciled by the Error-Correction Model: short run effects are negative and long run effects are positive. In the literature no attempt is made to subject the data to cross equation dependencies. This paper finds that these cross dependencies are necessary to identify the true relation between inflation and stock returns. Moreover this paper finds that taking into consideration the core inflation, instead of the CPI inflation, improves the evidence in favor of inflation irrelevance. Inflation irrelevance is very strongly supported with the 3SLS econometric procedure, and less strongly supported by SUR estimation, both procedures that incorporate cross equation dependencies. The strongest evidence of inflation irrelevance is justified theoretically by the elements of corporate finance: Net Present Values (NPVs) are the same in nominal terms and in real terms. Since stock prices are NPVs then they should not be affected by inflation. The evidence in this paper is in line with the recent research, on the inflation impact on stock returns, which finds inflation irrelevance. This common conclusion is highly important and crucial because it gives an enhanced rationality to the formation of stock prices in the financial markets.

\section{References}

Al-Nassar, N. S., \& Bhatti, R. H. (2019). Are common stocks a hedge against inflation in emerging markets? Journal of Economics and Finance, 1-35.

Anari, A., \& Kolari, J. (2001). Stock prices and inflation. Journal of Financial Research, 24(4), 587-602. https://doi.org/10.1111/j.1475-6803.2001.tb00832.x

Ang, A., Brière, M., \& Signori, O. (2012). Inflation and individual equities. Financial Analysts Journal, 68(4), 36-55. https://doi.org/10.2469/faj.v68.n4.3

Austin, A., \& Dutt, S. (2016). Do stock returns hedge inflation at long horizons? Applied Economics Letters, 23(13), 936-939. https://doi.org/10.1080/13504851.2015.1122725

Azar, S. A. (2010). Inflation and stock returns. International Journal of Accounting and Finance, 2(3-4), 254-274. https://doi.org/10.1504/IJAF.2010.034399

Azar, S. A. (2013). The spurious relation between inflation uncertainty and stock returns: evidence from the US. Review of Economics \& Finance, 3, 99-109.

Azar, S. A. (2014a). The determinants of US stock market returns. Open Economics and Management Journal, 1(1), 1-13. https://doi.org/10.2174/2352630001401010001

Azar, S. A. (2014b). Inflation and stock returns II. International Journal of Economics and Finance, 6(1), 208-216. https://doi.org/10.5539/ijef.v6n1p208

Boamah, M. I. (2017). Common stocks and inflation: an empirical analysis of G7 and BRICS. Atlantic Economic Journal, 45(2), 213-224. https://doi.org/10.1007/s11293-017-9543-9

Bodie, Z. (1976). Common stocks as a hedge against inflation. The Journal of Finance, 31(2), 459-470. https://doi.org/10.1111/j.1540-6261.1976.tb01899.x

Boudoukh, J., \& Richardson, M. (1993). Stock returns and inflation: A long-horizon perspective. The American Economic Review, 83(5), 1346-1355.

Brealey, R. A., Myers, S. C., \& Allen, F. (2017). Principles of Corporate Finance, McGraw-Hill, $12^{\text {th }}$ edition.

Campbell, J. Y., \& Vuolteenaho, T. (2004). Inflation illusion and stock prices. American Economic Review, 94(2), 19-23. https://doi.org/10.1257/0002828041301533

Ciner, C. (2015). Are equities good inflation hedges? A frequency domain perspective. Review of Financial Economics, 24, 12-17. https://doi.org/10.1016/j.rfe.2014.12.001

Ely, D. P., \& Robinson, K. J. (1997). Are stocks a hedge against inflation? International evidence using a long-run approach. Journal of International Money and Finance, 16(1), 141-167. https://doi.org/10.1016/S0261-5606(96)00039-3

Engle, R. F., \& Granger, C. W. (1987). Co-integration and error correction: representation, estimation, and testing. Econometrica: Journal of the Econometric Society, 251-276. https://doi.org/10.2307/1913236

Fama, E. F. (1981). Stock returns, real activity, inflation, and money. The American Economic Review, 71(4), 545-565.

Fama, E. F., \& Schwert, G. W. (1977). Asset returns and inflation. Journal of Financial Economics, 5(2), 115-146. 
https://doi.org/10.1016/0304-405X(77)90014-9

Feldstein, M. (1980). Inflation, tax rules and the stock market. Journal of Monetary Economics, 6(3), 309-331. https://doi.org/10.1016/0304-3932(80)90045-8

Fisher, I. (1930). The Theory of Interest, as Determined by Impatience to Spend Income and Opportunity to Invest it. New York: Macmillan.

Geske, R., \& Roll, R. (1983). The fiscal and monetary linkage between stock returns and inflation. The Journal of Finance, 38(1), 1-33. https://doi.org/10.1111/j.1540-6261.1983.tb03623.x

Gultekin, N. B. (1983). Stock market returns and inflation: evidence from other countries. The Journal of Finance, 38(1), 49-65. https://doi.org/10.1111/j.1540-6261.1983.tb03625.x

Jaffe, J. F., \& Mandelker, G. (1976). The" Fisher effect" for risky assets: An empirical investigation. The Journal of Finance, 31(2), 447-458. https://doi.org/10.1111/j.1540-6261.1976.tb01898.x https://doi.org/10.2307/2326616

Jarque, C. M., \& Bera, A. K. (1980). Efficient tests for normality, homoscedasticity and serial independence of regression residuals. Economics letters, 6(3), 255-259. https://doi.org/10.1016/0165-1765(80)90024-5

Jarque, C. M., \& Bera, A. K. (1987). A test for normality of observations and regression residuals. International Statistical Review/Revue Internationale de Statistique, 163-172. https://doi.org/10.2307/1403192

Modigliani, F., \& Cohn, R. A. (1979). Inflation, rational valuation and the market. Financial Analysts Journal, 35(2), 24-44. https://doi.org/10.2469/faj.v35.n2.24

Nelson, C. R. (1976). Inflation and rates of return on common stocks. The Journal of Finance, 31(2), 471-483. https://doi.org/10.1111/j.1540-6261.1976.tb01900.x

Solnik, B. (1983). The relation between stock prices and inflationary expectations: the international evidence. The Journal of Finance, 38(1), 35-48. https://doi.org/10.1111/j.1540-6261.1983.tb03624.x 